\title{
KESANTUNAN BAHASA DALAM STUDI LINGUISTIK PRAGMATIK
}

\author{
Akhmad Saifudin \\ Akhmad.saifudin@dsn.dinus.ac.id \\ Universitas Dian Nuswantoro
}

\begin{abstract}
The major aim of this paper is to provide a theoretical view of politeness in a pragmatic perspective. The study was conducted through literature studies on leading theories in language politeness studies, such as Brown and Levinson, Leech, and Ide as well as from observations of the current use of politeness phenomenon, namely interactions in cyberspace. The theoretical view of politeness is given as a result of observations about the reality of using politeness and the synthesis of existing theories.
\end{abstract}

Keywords: politeness, formality, social status, distance, sincerity

Tidak bisa kita pungkiri bahwa masalah kesantunan bahasa tidak bisa lepas dari teori kesantunan bahasa (politeness) Brown dan Levinson (1987). Semenjak munculnya teori ini, masalah kesantunan bahasa menjadi lahan penelitian yang marak di bidang linguistik. Muncul teori-teori dari banyak ahli bahasa yang mengkaji kesantunan bahasa. Beberapa ahli yang menyatakan tentang peran Brown dan Levinson dalam hubungannya dengan kesantunan bahasa di antaranya adalah Watts yang menyatakan bahwa teori kesantunan linguistik pertama kali dibuat oleh Brown dan Levinson dan itu muncul pada tahun 1987 yang disebut sebagai teori kesopanan 'menyelamatkan muka' (2003: 85). Eelen juga menyatakan bahwa nama Brown dan Levinson dianggap sinonim dengan kata politeness (2001: 3), dan “ Tidak mungkin berbicara tentang kesopanan tanpa mengacu pada teori Brown dan Levinson " (Kerbratorecchioni, 1997: 11).

Permasalahan kesantunan bahasa pada umumnya dikaji dalam bidang sosiolinguistik ataupun pragmatik. Di bidang sosiolinguistik karena kesantunan berhubungan dengan etika yang berlaku pada masyarakat dan peran sosial para partisipan percakapan. Sementara di bidang pragmatik karena masalah kesantunan bahasa berhubungan dengan bagaimana bahasa digunakan sebagai media komunikasi yang sangat berhubungan dengan konteks. Dalam pragmatik terkadang berbahasa santun belum tentu bermakna santun dan sebaliknya berbahasa tidak santun belum 
Akhmad Saifudin, Kesantunan Bahasa dalam Studi Linguistik Pragmatik

tentu juga bermakna tidak santun. Scovel (1998: 38) menyatakan bahwa pragmatik mewakili studi tentang apa yang orang maksudkan, yakni ketika mereka menggunakan bahasa dalam interaksi sosial normal; sedangkan sosiolinguistik mengacu pada studi tentang mengapa kita katakan, apa kepada siapa, kapan, dan di mana. Sementara menurut Eelen, bahwa meskipun perspektif pragmatik dan sosiolinguistik adalah berbeda satu sama lain, tetapi disatukan dalam hal teori kesantunan bahasa, yakni disatukan oleh sebuah fenomena yang dikaitkan dengan hubungan antara bahasa dan realitas sosial (2001: 1).

\section{METODE PENELITIAN}

Tulisan ini mencoba memberikan pandangan teoretis mengenai kesantunan bahasa dalam perspektif pragmatik. Kajian dilakukan melalui studi literatur tentang teori-teori terkemuka dalam kajian kesantunan bahasa, seperti Brown dan Levinson, Leech, dan Ide. Pandangan teoretis tentang kesantunan bahasa diberikan sebagai hasil dari pengamatan tentang realitas penggunaan kesantunan bahasa kontemporer serta hasil sintesis dari teori-teori yang sudah ada.

\section{HASIL DAN PEMBAHASAN}

\section{Teori Robin T. Lakoff}

Lakof adalah ahli linguistik formal mencoba untuk menetapkan bahasa sebagai suatu sistem dengan mengadopsi aturan pragmatis. Teorinya tentang kesantunan bahasa merupakan tanggapan dari teori Grice tentang prinsip kerja sama (1975) yang dianggapnya belum berhasil karena tidak menempatkan kesantunan dalam kerangka aturan pragmatis meskipun prinsip kerja sama didasarkan pada rasionalitas komunikatif komunikasi. Dalam percakapan informal normal prinsip kerja sama hampir tidak diikuti sepenuhnya dan meskipun Grice sudah memprediksi dengan teorinya yang lain tentang implikatur yang menjelaskan pengabaian maksim untuk maksud tertentu yang berbeda dengan tuturannya, belum juga dapat memuaskan Lakoff. 
Lakoff (1975) memandang fenomena kesantunan sebagai seperangkat strategi yang dipilih oleh pengguna bahasa. Sebagai sebuah strategi berarti selalu ada pilihanpilihan yang bergantung pada konteks. Tindak tutur santun artinya tuturan yang dilakukan diatur oleh kaidah kesantunan pragmatis, sedangkan tindak tutur nonsantun adalah ujaran yang dilakukan di luar norma kesantunan. Sehingga kesantunan menurut Lakoff (1975) adalah "sistem hubungan interpersonal yang dirancang untuk memfasilitasi interaksi dengan meminimalkan potensi konflik dan konfrontasi yang melekat dalam semua pertukaran manusia."

Lakoff mengusulkan dua aturan pragmatis sehubungan dengan tujuan untuk meminimalkan konflik antara penutur dan penerima pesan. Aturan tersebut adalah sebagai berikut.

1. Be Clear 'tuturkan dengan jelas', yang terdiri atas:

1.1. Maksim Kuantitas [sebutkan informasi sebanyak yang diperlukan dalam percakapan, tetapi tidak lebih].

1.2. Maksim kualitas [Hanya katakan apa yang Anda yakini benar berdasarkan pengetahuan dan bukti Anda sendiri].

1.3. Maksim hubungan

\subsection{Maksim cara}

1.5. Ringkas, hindari pernyataan yang membingungkan dan ambigu

Aturan pertama "Bersikaplah jelas" dicantumkan dan diturunkan dari prinsip kerja sama Grice dengan tujuan agar tidak terjadi kesalahfahaman dalam menerjemahkan maksud percakapan.

2. Be polite 'bersikaplah santun'

2.1. Jangan memaksakan

2.2. Berilah pilihan

2.3. Buat orang lain merasa baik, dan bersahabatlah. 
Akhmad Saifudin, Kesantunan Bahasa dalam Studi Linguistik Pragmatik

Jika dalam aturan pertama lebih mengutamakan isi/konten pertuturan, yang kedua ini lebih menghadirkan masalah sosial. Jadi apabila partisipan pertuturan nampak tidak mematuhi aturan pertama, ada kemungkinan yang menjadi prioritas adalah aturan kedua yang berkaitan dengan aturan sosial, yakni masalah kesantunan.

Dari ketiga aturan yang diberikan Lakoff dalam hal kesantunan, dapat dilihat bahwa Lakoff tetap menyadari bahwa masalah santun atau tidak sangat tergantung pada budaya masyarakatnya masing-masing. Setiap budaya mempunyai caranya masingmasing dalam mengidentifikasi kesantunan (Lakoff, 1975; Yule, 1996), dan karena itu Lakoff membagi kesantunan menjadi tiga jenis, yakni kesopanan berdasarkan jarak 'distance politeness', rasa hormat 'deference politeness', dan keakraban, 'camaraderie politeness'.

Dalam kesantunan 'jarak' terdapat kesetaraan antarpartisipan, setiap partisipan mempunyai 'wilayah otoritas'nya sendiri-sendiri. Budaya ini berlaku di kebanyakan masyarakat Eropa dan karena itu kesantunan jarak yang mengedepankan strategi untuk tidak memaksakan keinginan lebih banyak digunakan dalam masyarakat ini. Kesantunan yang kedua banyak berlaku di masyarakat Asia, yakni masyarakat yang mengutamakan harmoni dan menghindari konflik sosial. Konflik sosial dapat dihindari jika partisipan pertuturan menganggap bahwa apa pun yang dikatakan dan apa pun maksudnya dalam percakapan tergantung pada orang lain. Dalam kesantunan ini dibutuhkan sikap rendah hati dari salah satu atau kedua belah pihak partisipan. Aturan "berilah pilihan" sangat sesuai dengan kondisi masyarakat seperti ini. Sementara tipe kesantunan yang ketiga terjadi pada masyarakat yang lebih terbuka seperti di Amerika. Dalam masyarakat seperti ini sikap bersahabat, terbuka, dan menyenangkan adalah sebuah kesantunan.

\section{Teori Kesantunan Brown dan Levinson}

Berkaitan dengan kesantunan bahasa, Brown dan Levinson menggunakan istilah 'muka' sebagai sesuatu yang harus diperhatikan. Menurut mereka 'muka' adalah citra diri publik yang ingin diklaim oleh setiap anggota masyarakat untuk dirinya sendiri 
(Brown \& Levinson, 1987: 66). Jadi muka di sini bukan bermakna fisik, namun dapat dimaknai sebagai representasi keinginan diri yang dimunculkan di depan publik agar dipandang sesuai dengan keinginan empunya muka. Agar disebut sopan, maka partisipan pertuturan harus dapat menjaga agar muka tidak terancam, baik muka si penutur, mitra tutur, atau pihak lain yang terlibat. Dalam teori ini setiap tindakkan manusia dianggap mempunyai potensi untuk mengancam muka (face threatening act/FTA), sehingga perlu ada usaha untuk mengurangi atau menghilangkan ancaman tersebut.

Konsep muka dalam teori Brown dan Levinson sebenarnya terinspirasi dari konsep muka yang disebutkan oleh sosiolog terkemuka Erving Goffman. Dalam kaitannya dengan interaksi sosial, Goffman berpendapat bahwa masyarakat diatur oleh prinsip yang menetapkan bahwa setiap orang memiliki karakteristik sosial tertentu dan merupakan hak moralnya untuk mengharapkan evaluasi dan perlakuan yang tepat. Prinsip ini mengamanatkan pendapat lain bahwa orang harus menjadi apa yang mereka klaim, bukan menjadi orang lain (Goffman, 1956). Dalam mempresentasikan dirinya di depan masyarakat orang menggunakan apa yang disebutnya 'muka', yakni citra diri yang digambarkan dalam kaitannya dengan atribut sosial yang disepakati (Goffman, 1967). Goffman sendiri sebenarnya menggunakan istilah 'muka' dari konsep yang digunakan dalam masyarakat Tiongkok. Suatu masyarakat yang menganut ajaran Konfusianisme dalam hal menyelamatkan muka orang lain agar tidak kehilangan muka atau malu yaitu dengan istilah 'memberi muka'.

Jika Goffman (1967) menyatakan bahwa muka adalah atribut sosial, dalam arti bahwa muka itu diberikan oleh masyarakat yang telah mengenalnya, maka Brown dan Levinson (1987) menyatakan bahwa muka merupakan atribut pribadi yang dimiliki oleh setiap insan. Konsep muka dalam Goffman seperti layaknya sebuah gelar akademik yang diberikan oleh perguruan tinggi, harus dijaga dan dijalankan sesuai norma yang melekat pada gelar tersebut. Jika tidak maka gelar tersebut dapat diambil kembali oleh pemberinya. Sebaliknya, muka menurut pendapat Brown dan Levinson adalah atribut pribadi yang bersifat psikologis karena merupakan representasi dari 
Akhmad Saifudin, Kesantunan Bahasa dalam Studi Linguistik Pragmatik

keinginan empunya muka. Oleh Brown dan Levinson, muka dibedakan menjadi dua, yaitu muka positif dan negatif. Positif dan negatif di sini bukanlah bermakna konotatif baik dan buruk, melainkan untuk membedakan dua kutub jenis keinginan. Muka positif menunjuk pada nilai-nilai keakraban, persahabatan, solidaritas, penghargaan, dan ketidakformalan. Sementara muka negatif terkait dengan kemandirian dan kebebasan dari tekanan maupun paksaan dari pihak lain.

Dalam interaksi verbal dikatakan oleh Saeed bahwa muka seseorang berpotensi terancam (2003: 236). Di antara ancaman yang mengancam muka negatif adalah perintah, permintaan, saran, dan nasihat. Sementara potensi ancaman terhadap muka positif datang dari tindak verbal ketidaksetujuan, tuduhan, dan interupsi. Ancaman muka negatif dapat berpotensi merusak otonomi dan kebebasan orang, dan ancaman terhadap muka positif berpotensi merendahkan harga diri dan sosial individu. Tindak mengancam muka bukan hanya berlaku untuk mitra tutur atau pihak lain, namun juga berlaku untuk penuturnya. Misalnya ketika seseorang bertutur memberi nasihat kepada mitra tutur, ia pun harus memikirkan ancaman terhadap mukanya sendiri ketika mitra tutur tidak sepakat dengan nasihatnya.

Yule (1996: 61) menyatakan bahwa ada banyak cara untuk melakukan tindak menyelamatkan muka, karena setiap orang pada umumnya berusaha untuk menghormati keinginan muka orang lain. Yule (2010: 135) menjelaskan bahwa tindak menyelamatkan muka yang menekankan muka negatif seseorang mencerminkan kekhawatiran tentang pemaksaan (misalnya dengan menggunakan tuturan permohonan maaf), dan tindak penyelamatan muka yang menekankan wajah positif seseorang mencerminkan solidaritas dan menunjukkan tujuan bersama (misalnya dengan menunjukkan kesepakatan). Yule (1996: 62) juga menyatakan bahwa rasa hormat, menekankan pentingnya waktu atau perhatian orang lain, dan permintaan maaf atas pembebanan atau interupsi, yang dikaitkan dengan tindak penyelamatan wajah negatif disebut kesopanan negatif. Di sisi lain, ketika ada kecenderungan untuk menunjukkan solidaritas, menekankan bahwa kedua pembicara menginginkan hal yang sama, dan 
bahwa mereka memiliki tujuan yang sama, yang berorientasi pada penyelamatan wajah positif disebut kesopanan positif.

Brown dan Levinson mengusulkan kemungkinan strategi yang dapat dilakukan dalam hal tindak menyelamatkan muka berdasarkan risiko ancaman muka dari yang terbesar sampai terkecil. Strategi tersebut digambarkan sebagai berikut.

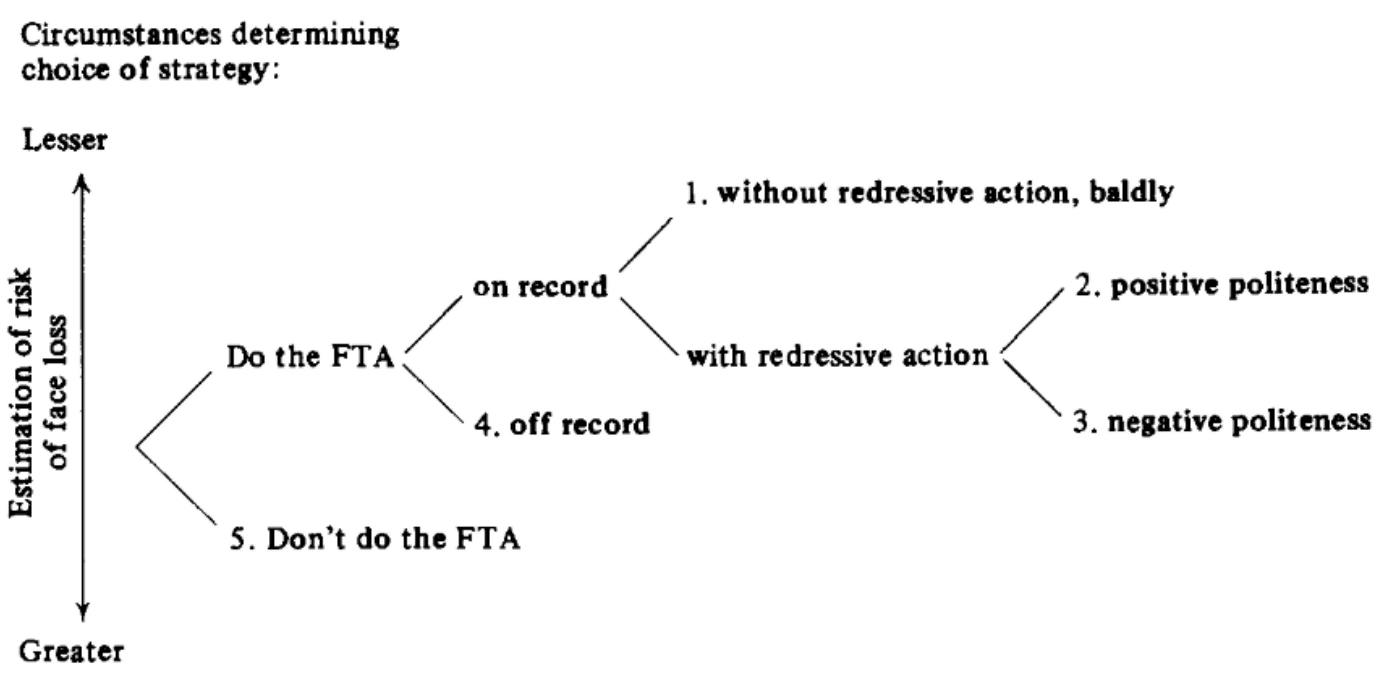

Gambar 1. Strategi Tindak Menyelamatkan Muka

[Sumber: Brown dan Levinson, 1987: 60]

Dari gambar 1 dapat diketahui bahwa semakin tinggi risiko keterancaman muka, semakin sedikit tuturan langsung yang dapat berdampak pada mengancam muka seseorang. Ketika risiko tinggi bahkan strategi yang dipilih adalah tidak melakukan FTA atau membatalkan tindak yang akan dituturkannya. Sebaliknya semakin kecil risiko FTA, maka strategi nomor 1 dapat digunakan, yaitu dituturkan secara langsung dan terus terang tanpa usaha untuk meminimalisir ancaman muka. Strategi pertama ini sesuai dengan prinsip kerja sama Grice karena mematuhi semua prinsip yang diusulkan oleh Grice.

Adapun sebenarnya yang benar-benar dapat dikatakan strategi adalah tiga strategi yang tersisa, yaitu strategi bertutur meminimalisir ancaman dengan kesantunan positif dan kesantunan negatif, serta strategi kesantunan off record, yaitu dengan bertutur 
Akhmad Saifudin, Kesantunan Bahasa dalam Studi Linguistik Pragmatik

secara tidak langsung atau tersamar untuk menghindari pembebanan yang tegas seperti hanya memberi isyarat alih-alih menuturkan permintaan langsung.

Strategi kesantunan positif dapat dipilih jika penutur ingin mengikis perbedaan jarak dan status dengan partisipan lainnya. Penutur ingin menciptakan suasana yang akrab dan mengedepankan persamaan di antara para partisipannya. Realisasi strategi tindak kesantunan positif dapat dilihat dalam gambar berikut.

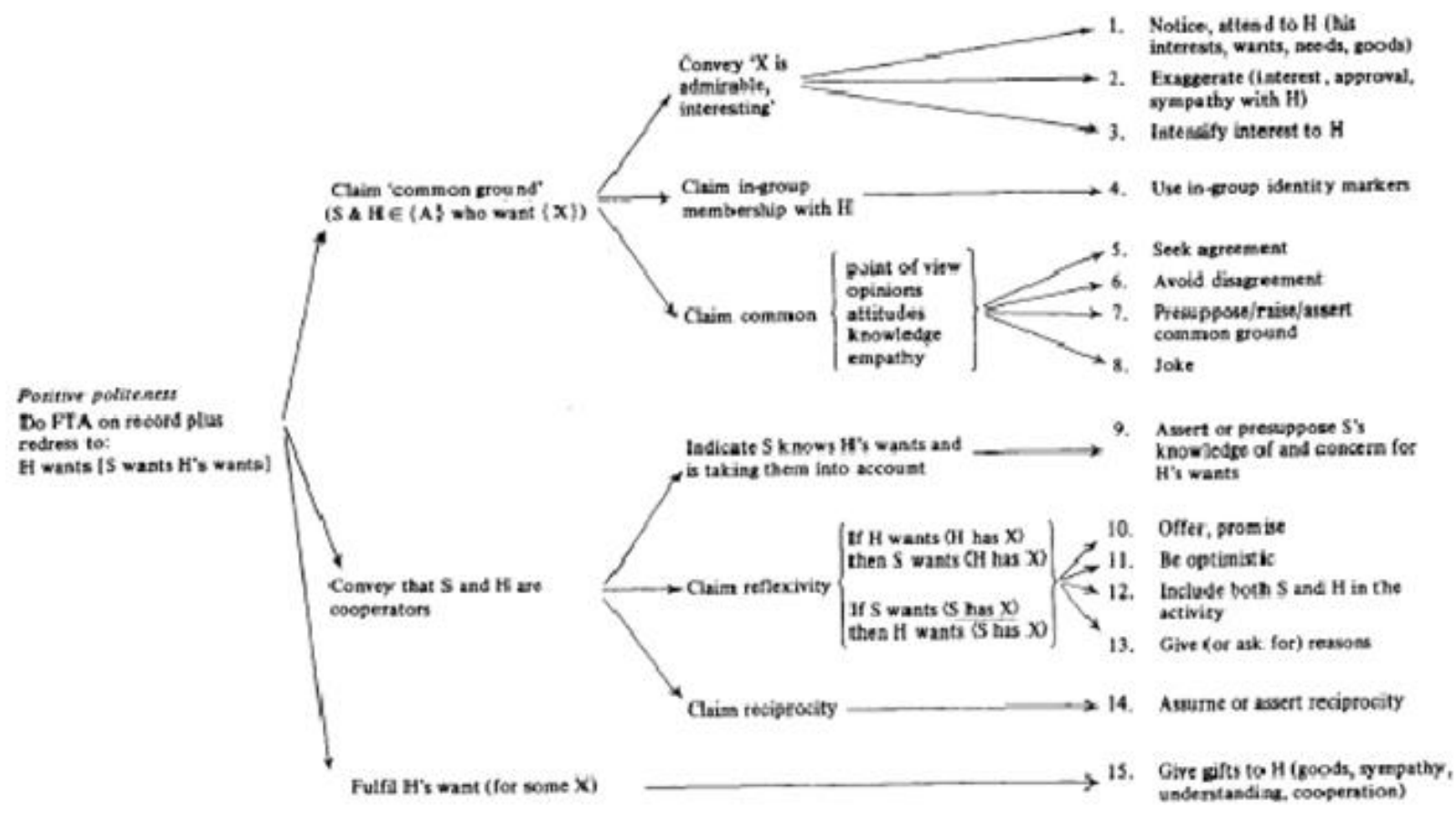

Gambar 2. Realisasi Strategi Kesantunan Positif

[Sumber: Brown dan Levinson, 1987: 110]

Realisasi strategi kesantunan positif diwujudkan dengan:

1. Notice, attend to $H$ (his interests, wants, needs, goods): strategi memberikan perhatian terhadap kepentingan, keinginan, kebutuhan, dan barang-barang mitra tutur, misalnya dengan tuturan "Model baru ya, bagus sekali rambutnya! Jalan yuk?"

2. Exaggerate (interest, approval, sympathy with $H$ ): strategi memberikan tuturan yang ekspresif (penekanan yang dilebihkan) terhadap minat, kesepakatan, dan simpati kepada mitra tutur. Dilakukan dengan cara pemberian intonasi, tekanan, 
irama yang menonjolkan sesuatu yang diperkirakan penutur akan menarik minat atau perhatian mitra tutur. Contohnya: "Wah, model baru ya, bagus sekali rambutnya! Jalan yuk?"

3. Intensify interest to $H$ : strategi ini dilakukan misalnya dengan cara membuat cerita yang bagus ya agar mitra tutur tertarik dan melibatkan dirinya dalam cerita itu. Ini adalah strategi membagi persamaan yang ada pada penutur dengan mitra tuturnya dengan lebih intensif. Contoh: Kemarin saya pergi ke rumah Anton. Kamu tahukan Anton itu seperti apa? Nah waktu aku ke sana ternyata dia itu tidak seperti yang kita duga, tahu nggak apa itu ... Dengan cara bercerita seperti itu, mitra tutur tergerak dan melibatkan dirinya berpihak yang sama dengan penuturnya.

4. Use in-group identity markers: strategi ini menggunakan tuturan yang mengidentifikasikan dirinya berada pada kelompok atau kelas yang sama dengan mitra tuturnya. Beberapa budaya tentu saja berbeda dalam mengaplikasikannya. Sebagai contoh adalah penggunaan sapaan (Sob, Bro, dll.), dialek serta jargon yang menunjukkan persamaan kelompok.

5. Seek agreement: Salah satu cara mengkaim kesamaan dengan mitra tutur adalah dengan mencari 'topik aman' untuk dibicarakan. Dalam banyak budaya sebelum membicarakan permintaan akan mengawali dengan pembicaraan hal-hal ringan seperti cuaca atau kesenangan yang tidak banyak menimbulkan pertentangan. Cara ini berdampak adanya kesepakatan dan terpenuhinya ide atau keinginan mitra tutur. Cara yang lain alam mencari kesepakatan adalah dengan mengulangnya 'repetition'. Misalnya "Kemarin Pak Hadi kemari.” Kemudian direspon "Kemarin ya."

6. Avoid disagreement: Hindari ketidaksepakatan adalah salah satu cara juga dalam rangka memperoleh kesamaan, meskipun fakta sebenarnya tidak sepakat. Kadang diperlukan cara-cara tertentu untuk menghindari ketidaksepakatan, misalnya dengan mengatakan "Ya saya setuju, tapi..." daripada langsung mengatakan "Tidak, saya tidak setuju.” Intinya adalah menghindari konflik meskipun dengan kesepakatan semu ataupun 'white lies'.

7. Presuppose/raise/assert common ground: Strategi menganggap/meningkatkan/ menegaskan persamaan ini biasanya dilakukan dengan obrolan ringan atau gosip. Penutur akan menempatkan dirinya mempunyai keinginan, pengetahuan, perasaan, 
Akhmad Saifudin, Kesantunan Bahasa dalam Studi Linguistik Pragmatik

dan pandangan yang sama dengan mitra tuturnya tentang hal-hal yang ringan atau sepele.

8. Joke: lelucon didasarkan pada pengetahuan yang sama akan sesuatu hal dan dapat meminimalisasi FTA.

9. Assert or presuppose S's knowledge of and concern for H's wants: Salah satu cara untuk menunjukkan bahwa $\mathrm{S}$ dan $\mathrm{H}$ adalah kooperator, dan dengan demikian berpotensi memberikan tekanan pada $\mathrm{H}$ untuk bekerja sama dengan $\mathrm{S}$, adalah dengan menegaskan atau menyiratkan pengetahuan tentang keinginan dan kemauan H untuk menyesuaikan keinginannya sendiri dengan mereka. Sebagai contoh: "Saya tahu kamu suka bunga Mawar, sayangnya saya tidak bisa mendapatkannya. Sebgai gantinya saya bawakan untukmu bunga Melati." (permintaan maaf + tawaran).

10. Offer, promise: tawaran dan janji adalah dua hal yang merepresentasikan penutur bekerja sama dengan mitranya.ini adalah salah satu cara untuk memuaskan muka positif mitra tuturnya karena menunjukkan niat baik penuturnya.

11.Be optimistic: Strategi optimis adalah keyakinan penutur mengasumsikan bahwa mitra tuturnya menginginkan terujudnya keinginan penutur untuk penutur (atau untuk keduanya) dan akan membantunya untuk mendapatkannya. Contoh adalah ketika seorang istri berbicara kepada suaminya Ketika suaminya akan pergi “Tunggu, kamu belum merapikan bajumu."

12.Include both $S$ and $H$ in the activity: strategi ini menggunakan kata ganti inklusif 'kami' untuk merefleksikan kerja sama dan mengurangi ancaman muka.

13.Give (or ask for) reasons: dengan memberikan atau memberikan alasan, mitra tutur akan mengetahui harapan atau keinginan penuturnya, sehingga diharapkan dapat bekerja sama. Memberi alasan adalah salah satu cara tidak langsung untuk mengatakan "saya dapat membantumu" atau "kamu dapat membantu saya".

14.Assume or assert reciprocity: car aini adalah dengan memberikan hak atau kewajiban timbal balik antara penutur dan mitra tuturnya. Misalnya dengan tuturan "Saya akan melakukan itu jika kamu melakukan ini."

15.Give gifts to H (goods, sympathy, understanding, cooperation): Setiap orang pada dasarnya ingin dihargai, diperhatikan, dan didengarkan. Sehingga pemberian hadiah 
atau penghargaan kepada mitra tutur (tidak selalu berwujud barang) akan memuaskan muka positifnya.

Strategi berikutnya adalah strategi kesantunan negatif, yakni tindakan perbaikan yang ditujukan ke wajah negatif mitra tutur dengan tujuan untuk menghargai keinginan mitra tutur agar kebebasan bertindaknya tidak terganggu. Adapun realisasi strateginya adalah sebagai berikut.

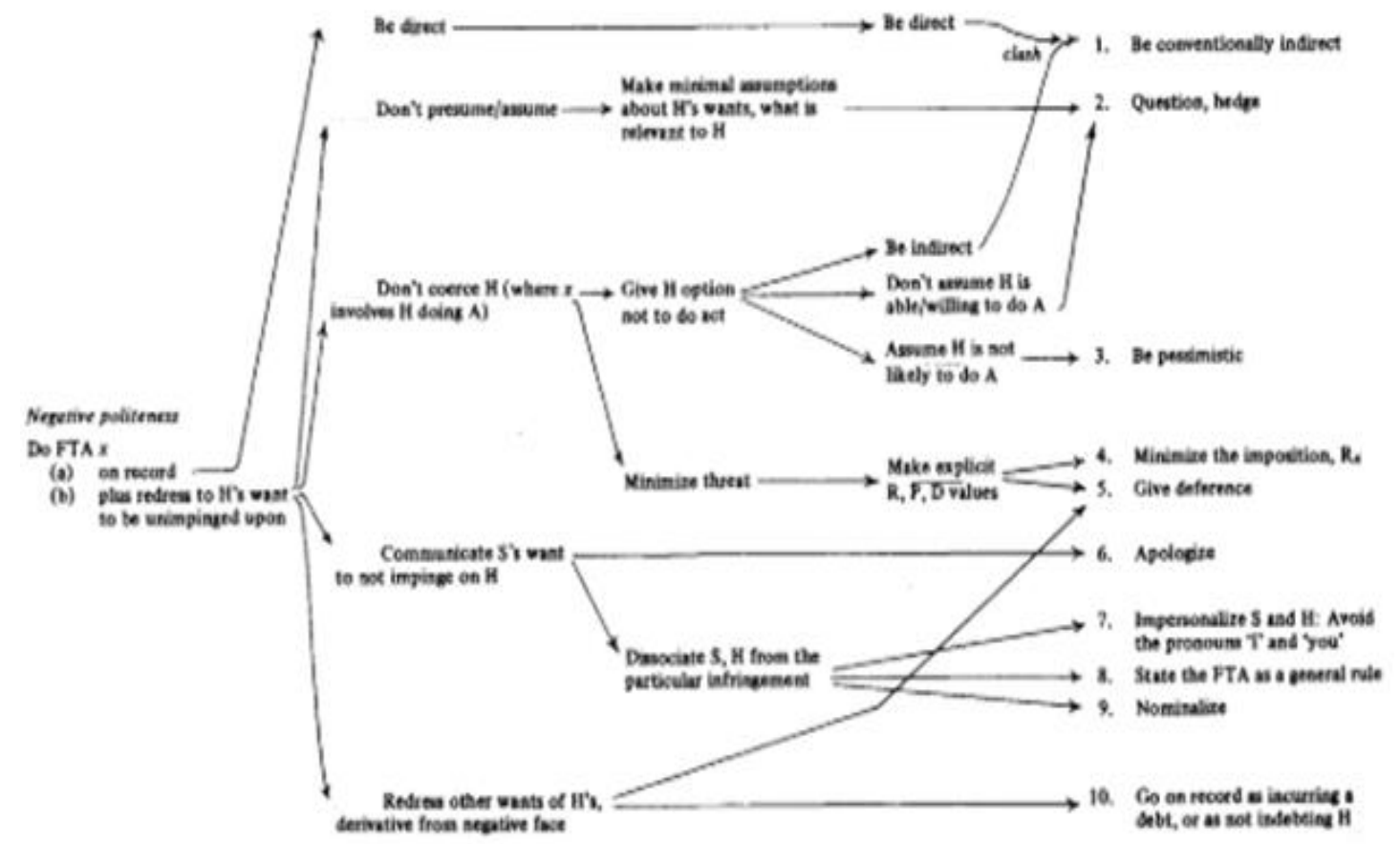

Gambar 3. Realisasi Strategi Kesantunan Negatif [Sumber: Brown dan Levinson, 1987: 131]

1. Be conventionally indirect: strategi ini dilakukan dengan cara menuturkan apa yang dikehendaki penutur dengan cara tidak langsung namun dapat dipahami oleh mitra tuturnya karena menggunakan tuturan yang sudah menjadi kebiasaan atau konvensional. Tuturan “Apakah kamu punya uang?” yang dituturkan oleh teman yang baru saja kecopetan akan dengan mudah diartikan bahwa ia membutuhkan uang dan dengan tuturan tersebut bermaksud meminjam uang.

2. Question, hedge: strategi menggunakan pertanyaan akan menghindari kesan bahwa penutur telah berpraduga atau memaksa mitra tuturnya dan penggunaan hedges 
Akhmad Saifudin, Kesantunan Bahasa dalam Studi Linguistik Pragmatik

'pagar' akan mengurangi atau mengubah derajat kepastian sesuatu. Dia cukup baik atau saya rasa dia tahu adalah contoh penggunaan hedge.

3. Be pessimistic: strategi bersikap pesimis dilakukan dengan cara secara eksplisit menuturkan keraguan agar tidak dinilai sebagai sebuah paksaan, apakah mitra tuturnya dapat memenuhi kehendak penuturnya atau tidak.

4. Minimize the imposition, $R_{x}$ : strategi ini dilakukan untuk meminimalkan beban permintaan pada mitra tuturnya. Sebagai contoh adalah dengan menggunakan kata just 'hanya' yang seolah-olah mengecilkan nilai sebuah permintaan

5. Give deference: strategi dengan cara memperlakukan mitra tuturnya sebagai seorang yang dihormati (superior) dengan cara merendah.

6. Apologize: permintaan maaf jelas akan mengurangi ancaman muka terhadap mitra tutur.

7. Impersonalize $S$ and $H$ : hindari personalisasi atau referensi secara langsung pada orang yang terlibat dalam FTA, seperti penggunaan kata 'aku' dan 'kamu' dalam tuturan.

8. State the FTA as a general rule: strategi menempatkan FTA sebagai aturan umum adalah cara yang aman untuk mengurangi FTA dalam pertuturan. Dengan mengungkapkan FTA sebagai aturan sosial atau sebuah kewajiban yang harus dilakukan oleh mitra tuturnya akan Nampak seperti bukan pemaksaan.

9. Nominalize: nominalisasi (membendakan) membuat tuturan lebih formal.

10. Go on record as incurring a debt, or as not indebting $H$ : strategi menuturkan secara eksplisit (jelas) bahwa penutur berutang (budi) kepada mitra tuturnya, atau mitra tuturnya tidak berutang apapun kepada penutur. Misalnya dengan menuturkan "Saya tidak akan pernah dapat membalas kebaikanmu."

Strategi terakhir adalah off record atau jika penutur ingin melakukan FTA, tetapi ingin menghindari tanggung jawab untuk melakukannya, ia dapat melakukannya secara off record (tidak dituturkan secara langsung) dan menyerahkan kepada mitra tuturnya untuk memutuskan bagaimana menafsirkannya. Terdapat dua strategi besar dalam strategi ini yakni menuturkan dengan cara implikatur dan samar atau ambigu. Untuk lebih jelasnya realisasi strategi ini dapat dilihat dari gambar dan penjelasan berikut. 


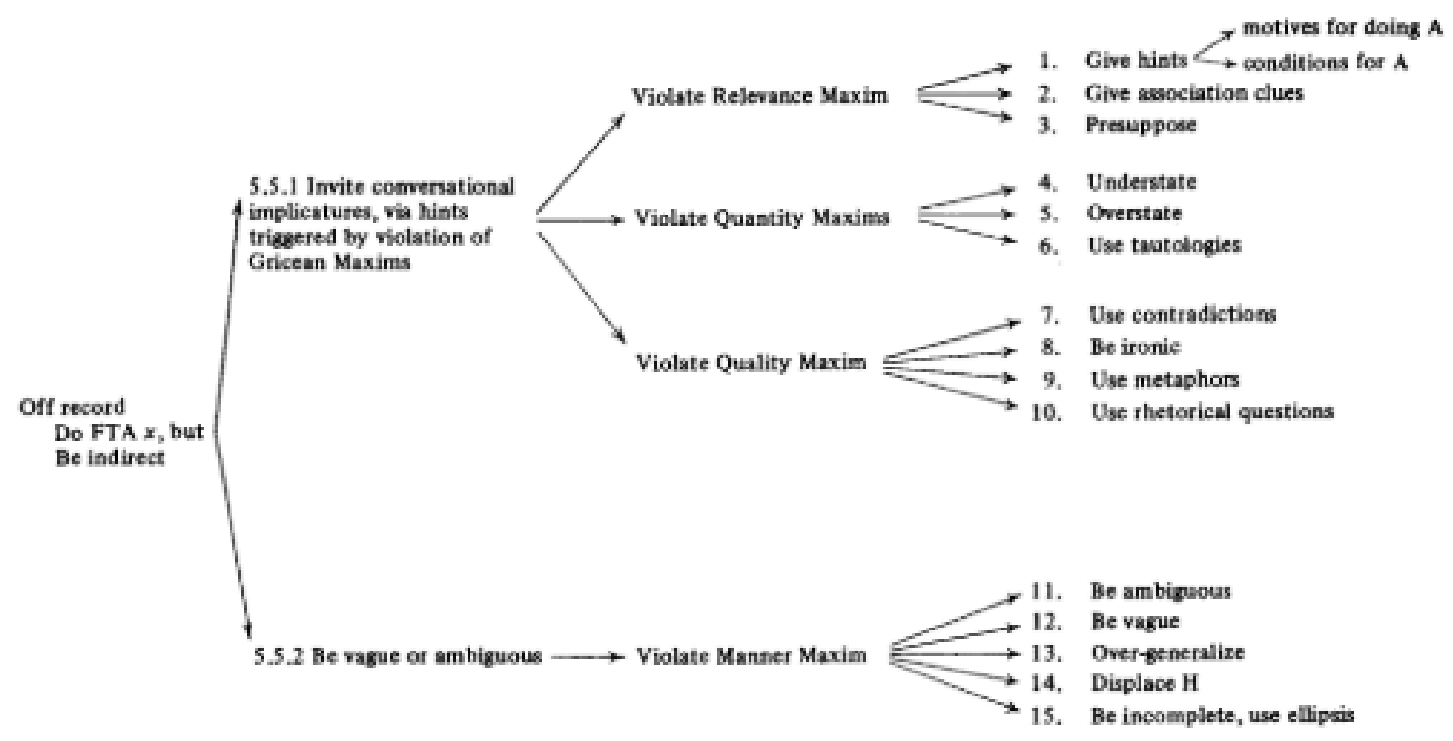

Gambar 4. Realisasi Strategi Kesantunan Negatif

[Sumber: Brown dan Levinson, 1987: 214]

1. Give hints: Jika penutur mengatakan sesuatu yang tidak relevan secara eksplisit, dia menggunakan isyarat tertentu untuk mengundang mitra tutur untuk mencari interpretasi tentang kemungkinan relevansinya. Mekanisme dasar di sini adalah pelanggaran terhadap maksim relevansi. Contoh: "panas ya di sini” (minta AC dinyalakan).

2. Give association clues: Ini adalah jenis strategi dengan menggunakan implikatur terkait yang dipicu oleh pelanggaran relevansi dengan menyebutkan sesuatu yang terkait dengan tindakan yang dibutuhkan mitra tutur, baik dengan menyatakan pengalaman penutur-mitra tutur atau dengan pengetahuan bersama terlepas dari pengalaman interaksional mereka. Contoh: "Jam 11 mau pulangkan? Saya juga sudah tidak ada pekerjaan lagi." (keinginan untuk numpang pulang).

3. Presuppose: dalam strategi ini tuturan dapat hampir sepenuhnya relevan dalam konteksnya, namun melanggar maksim relevansi hanya pada tingkat praanggapannya. Contoh "sudah dua kali saya mencucinya." Penggunaan sudah dua kali berarti sebuah bentuk protes atau resistensi atas ketidak puasan.

4. Understate: Dengan mengatakan lebih sedikit (yaitu, memberikan lebih sedikit informasi) daripada yang diperlukan atau dengan mengatakan lebih dari yang 
Akhmad Saifudin, Kesantunan Bahasa dalam Studi Linguistik Pragmatik

diperlukan, penutur mengundang mitra tuturnya untuk mempertimbangkan mengapa. Ini merupakan pelanggaran maksim kuantitas.

5. Overstate: kebalikan dari strategi keempat, yakni dengan menuturkan lebih dari yang dibutuhkan.

6. Use tautologies: menggunakan pernyataan yang diulang untuk melebih-lebihkan makna. Strategi ini juga melanggar maksim kuantitas karena sebenarnya tidak memberikan informasi sesuai yang dibutuhkan. Contoh "pencuri ya pencuri”.

7. Use contradictions: merupakan strategi yang melanggar maksim kualitas dengan cara menuturkan dua hal yang saling bertentangan. Contoh "Apakah kamu sependapat?" "Ya dan tidak."

8. Be ironic: Dengan mengatakan kebalikan dari apa yang penutur maksud, penutur secara tidak langsung menyampaikan makna yang dimaksudkannya, jika ada petunjuk bahwa makna yang dimaksudkannya sedang disampaikan secara tidak langsung. Petunjuk seperti itu mungkin saja prosodik (misalnya nasality), kinesik (misalnya seringai), atau hanya kontekstual. Contoh "Dia memang jenius!" (Dia bodoh).

9. Use metaphors: ini juga merupakan pelanggaran kualitas, yakni dengan menuturkan tuturan yang tidak bermakna literal. Contoh "Dia memang kutu buku."

10. Use rhetorical questions: Jenis strategi yang melanggar kualitas dengan menuturkan pertanyaan yang tidak membutuhkan jawaban. Ini sebenarnya mengingkari sifat pertanyaan yang seharusnya membutuhkan jawaban. Contoh "Aku harus bilang apa lagi?"

11. Be ambiguous: strategi ini melanggar maksim cara dengan menuturkan sesuatu yang ambigu atau mempunyai dua makna yang saling bertentangan. Contoh "Dia pintar berbicara." (dapat bermakna pujian atau justru penghinaan).

12. Be vague: strategi penuturan dengan cara tersamar bahkan tidak jelas apa objek yang dimaksudkannya. Contoh "Mungkin ada seseorang yang jahil."

13. Over generalize: Membuat simpulan yang terlalu umum, dapat menggunakan peribahasa yang sudah umum digunakan, misalnya "Siapa yang menanam akan memanen." 
14. Displace $H$ : penutur dengan sengaja tidak menuturkan dengan jelas siapa target FTAnya, dia berharap target sebenarnya yang dituju akan memahaminya sendiri dengan tuturannya tersebut. Misalnya Ketika A sedang makan bersama tunangan dan calon mertuanya minta diambilkan kecap kepada tunangannya, padahal letak kecap lebih dekat pada calon mertuanya.

15. Be incomplete, use ellipsis: strategi ini melanggar maksim cara sekaligus maksim kuantitas, karena menggunakan tuturan yang tidak lengkap dan bahkan tidak dituturkan (elipsis) atau seolah-olah menggantung. Contoh "Kalau begitu, saya pikir Anda..."

Dalam menentukan kriteria besar kecilnya FTA, Brown dan Levinson mendasarkan pada tiga hal, yaitu Distance (D/jarak sosial antara penutur dan mitra tutur), Power (P/tinggi rendahnya status/kekuasaan antara penutur dan mitra tuturnya), serta Rank (R/tingkatan bobot pembebanan berdasarkan situasi dan budaya yang berlaku). Ketentuan tersebut dapat dinyatakan dengan rumus sebagai berikut.

$$
\mathrm{W}_{\mathrm{x}}=\mathrm{D}(\mathrm{SH})+\mathrm{P}(\mathrm{SH})+\mathrm{Rx}
$$

W adalah nilai angka yang mengukur bobot FTA. Semakin jauh jarak sosial antara penutur dan mitra tuturnya akan semakin tinggi FTA-nya. Semakin besar atau tinggi kekuasaan/status mitra tutur, semakin besar pula FTA-nya bagi penutur. Semakin rendah kekuasaan/status mitra tutur akan semakin rendah pula tingkat FTAnya. Demikian juga dengan masalah Rank, semakin berat pembebanan dalam dalam tindak yang dilakukan semakin besar pula tingkat FTA-nya. Sebagai contoh dalam hal pembebanan adalah jika seseorang akan meminjam uang sebesar Rp.2.000 tentu saja FTA-nya jauh lebih rendah dibanding dengan meminjam uang sebesar Rp.1.000.000,00.

\section{Teori Kesantunan Geoffrey Leech}

Teori Leech tentang kesantunan bahasa dinyatakan dalam sebuah prinsip kesantunan (PK) yang di dalamnya terdapat enam maksim (Leech, 1983, 2014). Menurut Leech, prinsip kesantunan dapat menjadi pelengkap dari prinsip kerja sama 
Akhmad Saifudin, Kesantunan Bahasa dalam Studi Linguistik Pragmatik

yang dikemukakan oleh Grice. Bagi Leech (1983: 81), prinsip kesantunan menyatakan bahwa seseorang harus 'memaksimalkan ekspresi keyakinan yang sopan, meminimalkan ekspresi keyakinan yang tidak sopan'. Dia membaginya menjadi enam prinsip: maksim kearifan (tact maxim), maksim kedermawanan (generosity maxim), maksim pujian (approbation maxim), kerendahan hati (modesty maxim), maksim kesepakatan (agreement maxim), dan maksim simpati (sympathy maxim).

Maksim kearifan mencakup dua submaksim, yaitu (1) buatlah kerugian orang lain sekecil mungkin dan (2) buatlah keuntungan orang lain sebesar mungkin. Dalam hal ini yang disebut sopan adalah jika tuturan penutur lebih mengutamakan kepentingan atau keuntungan mitra tuturnya. Contoh adalah tuturan: "Silakan diminum Pak, nanti keburu dingin."

Maksim berikutnya sebenarnya konsekuensi dari maksim kearifan, yakni maksim kedermawanan atau juga disebut maksim kemurahan hati, yang mengutamakan untuk meminimalkan keuntungan diri sendiri dan memaksimalkan keuntungan orang lain. Sebagai contoh adalah tuturan "Saya yang akan menunggunya Pak. Bapak istirahat saja di rumah."

Maksim ketiga dan keempat sebenarnya juga merupakan pasangan yang satu menjadi konsekuensi dari maksim satunya seperti halnya dalam maksim satu dan dua. Kedua maksim tersebut adalah maksim pujian dan kerendahan hati. Maksim pujian berorientasi pada mitra tutur, yakni untuk memberikan penghargaan atau pujian, sementara maksim kerendahan hati berorientasi kepada diri sendiri untuk tidak memuji diri sendiri dan bertutur rendah hati. Sebagai contoh "Terima kasih atas bantuan Bapak, Saya tidak akan menyelesaikan pekerjaan ini tanpa kebaikan Bapak.”

Maksim kelima dari prinsip kesantunan Leech adalah maksim kesepakatan yang mencakup upaya untuk menghindari ketidaksepakatan dan sebaliknya memaksimalkan kesepakatan antara diri dan orang lain. Sebagai contoh tuturan santun dalam maksim ini adalah "Benar Pak. Menurut saya memang sebaiknya seperti itu." 
Maksim terakhir adalah maksim simpati, yakni tuturan yang mengekspresikan rasa simpati dan menghindari tuturan yang bersifat antipati. Sikap acuh yang tidak mempedulikan apa yang dilakukan atau apa yang terjadi pada orang lain bukanlah hal yang santun dalam berinteraksi sosial. Ungkapan rasa simpati seperti turut berbela sungkawa ketika orang lain mendapat musibah atau ucapan selamat ketika orang lain berbahagia adalah contoh dari realisasi maksim ini.

Apabila dicermati, kesantunan Leech sangat tergantung pada situasi, yaitu dapat bersifat kompetitif (jika tujuan ilokusinya bersaing dengan tujuan sosial, seperti bertanya atau meminta), konvivial/ramah (jika tujuan ilokusinya sejalan dengan tujuan sosial, seperti tawaran, ajakan, janji, ucapan selamat dan terima kasih), kolaboratif (jika tujuan ilokusinya menghiraukan tujuan sosial, seperti menyatakan, menegaskan dan memberitahukan), dan bersifat konflik, ketika bertentangan dengan tujuan sosial, seperti mengancam dan menuduh. Adapun dalam penentuan jenis kesantunannya dipengaruhi oleh skala-skala penentu, seperti skala untung-rugi, opsionalitas, ketidaklangsungan, otoritas, dan skala jarak sosial.

\section{Teori Kesantunan Ide Sachiko}

Teori kesantunan Ide didasarkan pada pandangannya mengenai karakteristik bahasa Jepang dan masyarakatnya. Ia melihat kesantunan bahasa sebagai unsur terpenting dalam menjaga kelancaran berkomunikasi dan harmoni dalam masyarakat. Berbeda dengan teori kesantunan yang disampaikan oleh ahli-ahli Barat, khususnya Brown dan Levinson, Ide menganggap bahwa kesantunan bukan hanya sebagai strategi, melainkan suatu keharusan yang harus digunakan dengan melihat konteks sosial dan situasional. Konteks sosial yang dimaksud adalah posisi atau status penutur jika dibandingkan dengan mitra tutur atau orang yang dibicarakan. Sementara konteks situasional adalah situasi pada saat terjadinya pertuturan (formalitas).

Teori Ide berpusat pada apa yang disebutnya wakimae, yaitu norma sosial yang menghendaki anggotanya berperilaku yang sesuai aturan masyarakat (Ide, 1982; Saifudin, 2010; Saifudin et al., 2008). Dalam arti bahwa orang Jepang menggunakan 
Akhmad Saifudin, Kesantunan Bahasa dalam Studi Linguistik Pragmatik

kesantunan bahasa karena tuntutan norma masyarakat Jepang, ia tidak mempunyai kebebasan untuk memilih strategi bertutur berdasarkan faktor keinginan pribadi. Ia harus dapat melihat siapakah ia, siapa mitra tuturnya, seperti apa situasinya, dan kemudian baru menggunakan pilihan bahasa berdasarkan konteks tersebut. Dalam menggunakan pilihan bahasa tersebut, orang Jepang terikat pada aturan bahasa yang mengatur penggunaan bahasa hormat, yang disebut keigo 'honorifics'. Sistem keigo ini tidak terdapat dalam bahasa Inggris atau bahasa Barat lainnya.

Penggunaan bahasa hormat digunakan pada elemen nominal dan elemen predikatif (Ide, 1982). Pada elemen nominal, bahasa hormat digunakan pada referensi persona dan prefiks nomina (perfiks $o$ dan $g o$ ). Referensi persona mencakup kata ganti persona (watashi, boku, atashi, omae, anata, dst), sufiks kata sapaan (-san, -sama, sensei), dan sapaan yang berkaitan dengan profesi, seperti shachou dan gakuchou, yang penggunaannya dapat berdiri sendiri atau menyertai nama keluarga sebagai sufiks.

Dalam elemen predikatif, yakni unsur predikat dalam kalimat terbagi menjadi dua. Pertama adalah referent honorifics, yaitu penggunaan predikat hormat berdasarkan referensi pelaku dan addressee honorifics yang berdasarkan mitra tutur dan formalitasnya. Referent honorifics masih terbagi menjadi dua, yakni subject honorifics $(\mathrm{SH})$ dan object honorifics $(\mathrm{OH})$. Predikat $\mathrm{SH}$ digunakan pada kalimat yang menekankan pada pelaku atau subjek, yakni orang di luar kelompok (soto-mono), sementara predikat $\mathrm{OH}$ tidak menekankan pada subjek karena pelakunya adalah penuturnya atau orang dalam kelompok (uchi-mono). Dalam istilah bahasa Jepang SH dapat disamakan dengan sonkeigo dan $\mathrm{OH}$ adalah kenjougo. Apabila kita menuturkan aktifitas dari orang lain (soto-mono) yang posisinya 'lebih' dari kita maka digunakan predikat SH atau sonkeigo. Sebagai contoh adalah "Tanaka-sensei wa gakkou made oaruki-ni natta." 'Prof. Tanaka berjalan kaki sampai ke sekolah.' (penggunaan $o \sim n i$ naru adalah penanda $\mathrm{SH}$ /sonkeigo). Kemudian apabila kita menuturkan aktifitas kita atau orang di dalam kelompok kita (uchi-mono) kepada orang lain (soto-mono) yang posisinya 'lebih' dibandingkan dengan kita maka digunakan $\mathrm{OH} /$ kenjougo. Contoh "Watashi wa Tanaka-sensei nis ono wake wo o-tazune-shita." "Saya menanyakan 
alasannya kepada Prof. Tanaka.' (penggunaan pola o suru adalah penanda $\mathrm{OH} /$ kenjougo).

Element predikatif yang kedua yakni addressee honorifics $(\mathrm{AH})$ atau dalam tata bahasa tradisional disebut dengan teineigo 'bahasa sopan' digunakan berdasarkan siapa mitra tuturnya dan formalitasnya. AH atau teineigo ini ditandai dengan predikat berakhiran -masu pada predikat verba dan kopula -desu atau -de gozaimasu pada predikat nomina atau ajektiva. Penggunaan AH menandai adanya jarak di antara penutur dan mitra tuturnya. Sebagai contoh "Taro wa gakusei desu." 'Taro seorang pelajar' Kopula desu digunakan ketika mitra tuturnya orang yang 'lebih' dibanding penutur atau situasi pada saat dituturkan adalah formal seperti di dalam rapat atau pada saat perkuliahan.

Honorifiks bahasa Jepang yang sudah dipaparkan sebenarnya merupakan hasil dari pematuhan atas aturan-aturan sosial dalam masyarakat Jepang. Menurut Ide ada bermacam faktor sosial dan psikologis yang berperan dalam penggunaan honoriks (1982). Menurutnya, terdapat empat faktor utama yang terlibat, yakni posisi sosial, kekuasaan, usia, dan formalitas, yang kemudian dijabarkan dalam tiga aturan mendasar dan satu aturan utama, yaitu:

\section{Aturan 1: 'Sopanlah kepada orang yang posisi sosialnya lebih tinggi'}

Dalam masyarakat Jepang, yang termasuk posisi sosial tinggi adalah Kaisar dan keluarganya, keluarga terpandang, profesor, dokter, anggota parlemen, dan orangorang yang mempunyai profesi lain yang dianggap tinggi.

\section{Aturan 2: 'Sopanlah kepada orang yang mempunyai kuasa"}

Kuasa dalam konteks ini bermakna luas, dalam konteks perusahaan seorang direktur lebih berkuasa dari bawahannya, senior lebih berkuasa dari yuniornya. Orang yang menjalankan profesinya lebih berkuasa dibandingkan dengan 'klien'nya. Sebagai contoh dokter lebih berkuasa dari pada pasiennya, polisi lebih berkuasa dari pelanggar, 
Akhmad Saifudin, Kesantunan Bahasa dalam Studi Linguistik Pragmatik

guru lebih berkuasa dari muridnya. Kuasa juga dimiliki oleh orang yang dibutuhkan, misalnya orang yang memberi hutang, pembeli, pelanggan, dan sebagainya.

\section{Aturan 3: 'Sopanlah kepada orang yang lebih tua'}

Dalam masyarakat Jepang, usia masih menjadi faktor penting dalam membedakan posisi sosialnya. Apalagi masyarakat Jepang mempunyai kecenderungan bertindak atas nama kelompok. Dalam sebuah kelompok yang biasanya homogen, faktor usia menjadi salah satu pembeda yang nyata di antara anggota kelompok.

Dalam pelaksanaannya tentu saja dapat terjadi konflik ketika dua atau bahkan ketiga aturan tersebut muncul bersamaan. Biasanya satu aturan akan lebih dominan dibandingkan dengan aturan lainnya. Sebagai contoh ketika seorang pasien yang lebih tua usianya akan menggunakan bahasa sopan kepada dokter yang usianya lebih muda. Secara umum jika disimpulkan, relatif urutan aturan ketika berlaku pada mitra tutur 'addressee' adalah 2, 1, dan 3. Sementara kepada orang ketiga 'referent' adalah 1, 3, dan 2 .

\section{Aturan Utama: 'Sopanlah dalam situasi formal'}

Formalitas adalah faktor yang paling utama dalam penggunaan honorifiks. Situasi formal adalah situasi yang mengharuskan orang untuk berhati-hati dalam berperilaku, termasuk perilaku verbal. Dalam situasi formal selalu ada aturan yang yang sudah disepakati bersama dan jika dilanggar akan mengganggu harmoni dalam masyarakat.

Formalitas sebuah peristiwa percakapan menurut Ide ditentukan oleh beberapa hal, seperti formalitas di antara peserta tutur (partisipan), formalitas acara, dan formalitas topik percakapan. Formalitas akan terjadi jika di antara peserta tutur tidak saling mengenal dan tidak terdapat solidaritas. Jika seseorang bertutur dengan orang asing yang tidak diketahui latar belakang maupun karakternya, maka ia akan bersikap formal. Pun dengan tidak adanya rasa solidaritas. Solidaritas dibentuk oleh para 
anggota yang mempunyai kesamaan kepentingan dan tanggung jawab. Solidaritas terdapat pada orang-orang dengan kesamaan ideologi, sosial, budaya, keluarga, dan sebagainya. Berikutnya, formalitas acara terjadi pada acara-acara seperti upacara pemakaman, pernikahan, khutbah keagamaan, rapat, dan perkuliahan. Dalam acara formal orang akan bersikap formal terlepas dari faktor posisi sosial, kekuasaan, dan usianya. Terakhir, formalitas topik terjadi pada percakapan dengan topik serius. Wawancara dan percakapan tentang bisnis atau politik tentu akan lebih formal dibanding dengan percakapan dengan tema hobi atau hiburan.

Dari paparan di atas dapat disimpulkan bahwa teori Ide melihat fenomena honorifiks berdasarkan dua hal, yaitu aturan sosial dan aturan kebahasaan. Sebagai makhluk sosial orang Jepang mempunyai konsekwensi untuk menjamin tegaknya harmoni masyarakat dengan berlaku sesuai kehendak dan tujuan sosial, termasuk dalam penggunaan bahasa. Ini berbeda dengan teori-teori Barat pada umumnya yang lebih menekankan pada kebutuhan psikologis individu, sehingga memungkinkan seseorang lebih aktif memilih strategi sesuai kondisi. Inilah yang disebut Ide sebagai volition yang dapat berlaku di Barat. Orientasi volition lebih kepada maksud individu dengan mempertimbangkan 'muka' mitra tuturnya, sementara di Jepang berlaku wakimae (istilah dalam bahasa Inggris disebut discernment) yang lebih berorientasi kepada kehendak masyarakat.

\section{Fenomena Kesantunan Bahasa Kontemporer}

Berbagai pengamatan fenomena kesantunan telah melahirkan banyak teori tentang kesantunan bahasa. Meskipun ada perbedaan, yang terutama karena perbedaan budaya masyarakatnya, dapat diambil simpulan bahwa tujuan kesantunan adalah dalam rangka menjaga hubungan sosial yang harmoni, baik secara individu maupun masyarakat. Perbedaan yang ada semata-mata karena 'wadah' dan 'media'. Wadah di sini berarti masyarakatnya, dan 'media' adalah bahasa yang digunakan, yang masingmasing mempunyai karakter sendiri-sendiri. Kesantunan bahasa pada masyarakat Barat yang diwakili oleh teori Brown dan Levinson dilatarbelakangi oleh masyarakatnya yang lebih berorientasi pada kebebasan individu, sementara teori Ide dilatarbelakangi 
Akhmad Saifudin, Kesantunan Bahasa dalam Studi Linguistik Pragmatik

oleh masyarakatnya yang berorientasi pada kepentingan kelompoknya. Dalam hal media bahasa, pada umumnya bahasa Barat tidak memiliki sistem honorifiks seperti halnya bahasa Jepang, sehingga wajar jika terdapat perbedaan dalam penggunaannya.

Dalam satu setengah dekade terakhir ini, perkembangan sosial dan interaksinya mengalami perubahan yang signifikan. Perkembangan ini ditandai dengan maraknya penggunaan media sosial yang berbasis internet, seperti whatsapp (WA), Twitter, Facebook, Instagram dan Youtube. Perkembangan ini menciptakan masyarakat baru yang disebut masyarakat dunia maya. Sebuah masyarakat baru yang anggotanya dapat terbatas, seperti WA, sampai dengan masyarakat yang anggotanya tidak terbatas bahkan melewati batas negara yang masing-masing tidak dapat dikenali identitasnya dengan mudah. Bisa jadi, akun yang seharusnya menjadi representasi diri tidak dibuat dengan sebenarnya.

Dalam masyarakat dunia maya yang anggotanya terbatas dan identitas aslinya dapat dikenali setiap anggotanya, penggunaan bahasanya, termasuk bahasa kesantunan, tidak berbeda jauh dengan penggunaan di dalam masyarakat biasa. Masih tergantung pada status peserta tutur dan formalitasnya. Namun, dalam media sosial yang tidak terbatas, karena identitas partisipannya tidak jelas (dapat diketahui tetapi dengan usahausaha tertentu yang membutuhkan keterampilan di bidang IT), penggunaan kesantunan menjadi tidak dapat dikontrol dengan mudah, baik bahasa maupun konten bahasanya. Usaha seperti yang dilakukan oleh pemerintah, misalnya dengan membuat Undangundang IT, ataupun yang dilakukan oleh pembuat media sosialnya, seperti Facebook, Twitter, dan Youtube tidak terlalu efektif. Masih banyak beredar konten-konten dan tuturan yang tidak santun, fiktif, dan tidak sesuai dengan norma. Norma yang berlakupun, yang dapat dijadikan pedoman sulit karena partisipan tidak terbatas dan melampaui batas bangsa atau budaya. Lantas, bagaimana kemudian kesantunan bahasa yang berlaku di sini? Apakah teori kesantunan yang sudah ada dapat berlaku di sini?

Teori kesantunan yang sudah ada, seperti teori Brown dan Levinson, Leech, maupun Ide, pada dasarnya sudah melewati pengamatan dan penelitian yang mendalam. 
Sehingga dalam hal ini memungkin untuk tetap dapat diberlakukan. Seperti yang sudah dipaparkan sebelumnya, tujuan kesantunan adalah dalam rangka memelihara harmoni dalam masyarakat, termasuk masyarakat dunia maya ini. Mungkin faktor-faktor penentu seperti status sosial dan hubungan kedekatan tidak dapat sepenuhnya berlaku di sini. Akan tetapi, faktor formalitas, seperti yang dipaparkan oleh Ide dapat berlaku. Diperlukan kesadaran dari partisipan untuk bertutur santun dengan mempertimbangkan faktor formalitas, terutama formalitas topik pertuturan dan juga acara. Ketika topik pertuturan mengenai kematian misalnya, akan tidak santun jika ada partisipan yang bertutur melukai hati orang yang sedang ditimpa kemalangan.

Melihat fenomena penggunaan bahasa dalam masyarakat dunia maya, terdapat perbedaan signifikan antara interaksi fisik di masyarakat nyata dan maya. Perbedaan itu adalah identitas peserta tuturnya. Di dunia maya identitas peserta tutur tidak dapat diketahui secara optimal, latar belakangnya apa, usia berapa, dan sebagainya. Tentu saja hal ini berpengaruh pada penggunaan kesantunan bahasa. Dalam dunia maya yang terpenting adalah konten atau isi tuturan. Santun adalah jika isi tuturan tidak menghina, merendahkan menyerang, atau mempermalukan orang lain. Santun juga berarti penuturnya tidak angkuh dan tulus dalam menyampaikan tuturannya. Hal ini berarti diperlukan kejujuran atau ketulusan (sincerity) dalam setiap interaksi. Bahkan sebenarnya faktor ketulusan ini juga berlaku pada interaksi fisik pada masyarakat riil. Masalah kesantunan bukan hanya pada bentuk bahasanya (Saifudin, 2020), bukan pula semata-mata pada status atau 'ketidaklangsungan', melainkan juga pada isi tuturan. Orang dapat saja bertutur santun, tetapi isinya merendahkan orang. Hal ini tidak dapat dikatakan santun.

\section{SIMPULAN}

Sudah banyak pembahasan tentang kesantunan dan sudah banyak pula yang menghasilkan teori kesantunan. Teori-teori yang dihasilkan tentu saja bukan merupakan sesuatu yang mutlak harus diimplementasikan. Ada banyak faktor yang menyebabkan teori kesantunan dapat bersifat relatif. Perbedaan budaya, bahasa, dan media berpengaruh pada penggunaan kesantunan. Dalam tulisan ini sudah dipaparkan 
Akhmad Saifudin, Kesantunan Bahasa dalam Studi Linguistik Pragmatik

bagaimana penggunaan kesantunan yang berorientasi pada 'muka' yang ternyata tidak dapat sepenuhnya berlaku pada bahasa Jepang yang mempunyai karakter masyarakat dan bahasa yang berbeda. Kesantunan yang satu berorientasi pada individu dan bahasa yang digunakan tidak mempunyai sistem honoriks, yang lain berorientasi pada kelompok dan mempunyai sistem honorifiks.

Teori-teori yang sudah ada dapat menjadi referensi bagi penelitian di bidang kesantunan bahasa. Kekurangan satu teori dapat dilengkapi dengan teori yang lain. Penggunaan teori yang tidak cocok dapat digantikan dengan teori lain yang lebih sesuai. Satu hal yang menjadi tambahan sebagai hasil dari penelitian ini adalah faktor ketulusan (sincerity) dalam bertutur. Kesantunan bukan hanya masalah status sosial, jarak sosial, dan formalitas. Masalah ketulusan dalam isi tuturan juga penting. Isi tuturan yang santun adalah jika penutur tidak angkuh dan menyampaikan dengan tulus, serta tidak menghina, merendahkan, menyerang, atau mempermalukan orang lain.

\section{REFERENSI}

Brown, P., \& Levinson, S. C. (1987). Politeness: Some Universals in Language Usage. Cambridge University Press.

Eelen, G. (2001). A Critique of Politeness Theories. St. Jerome Publishing.

Goffman, E. (1956). The Presentation of Self in Everyday Life. Penguin.

Goffman, E. (1967). On Face-Work: An Analysis of Ritual Elements in Social. In Interactional ritual: Essays on face-to-face behavior. Anchor Books.

Grice, P. (1975). Logic and Conversation. In Syntax and Semantics (Vol. 3, pp. 41-58). https://doi.org/10.1111/j.1365-2664.2006.01229.x

Ide, S. (1982). Japanese Sociolinguistics Politeness and Women's Language. Lingua, 57, 357-385.

Kerbrat-orecchioni, C. (1997). A multilevel approach in the study of talk-in-interaction. Pragmatics, 7(1), 1-20.

Lakoff, R. (1975). Language and Women's Place. Harper \& Row Publishers.

Leech, G. (1983). Principles of Pragmatics. Longman.

Leech, G. (2014). The Pragmatics of Politeness. Oxford University Press. https://doi.org/10.1093/acprof:oso/9780195341386.001.0001

Saeed, J. I. (2003). Semantics (2nd ed.). Blackwell Publising.

Saifudin, A. (2010). Analisis Pragmatik Variasi Kesantunan Tindak Tutur Terima Kasih Bahasa Jepang dalam Film Beautiful Life Karya Kitagawa Eriko. LITE, 6(2), 172-181.

Saifudin, A. (2020). Implikatur percakapan dalam studi linguistik pragmatik (Conversational Implicature in Pragmatic Linguistic Studies). Jalabahasa, 16(1), 15-24. 
159 Lก̉ TEE, Volume 16 Nomor 2, September 2020

Saifudin, A., Aryanto, B., \& Budi, I. S. (2008). Analisis Fungsi Pragmatik Tindak Tutur Pertanyaan dalam Percakapan Bahasa Jepang antara Wisatawan Jepang dan Pemandu Wisata Indonesia di Candi Borobudur. Lite: Jurnal Bahasa, Sastra, Dan Budaya, 4(1), 8-15. http://publikasi.dinus.ac.id/index.php/lite/article/ view/441/976

Scovel, T. (1998). Psycholinguistics. Oxford University Press.

Watts, R. J. (2003). Politeness. Cambridge University Press.

Yule, G. (1996). Pragmatics. Oxford University Press.

Yule, G. (2010). The Study of Language (Fourth Edi). Cambridge University Press. 